\title{
Fronting the Return of Foreign Terrorist Fighters: the Rise and Fall of ASEAN Border Cooperation to Com- bat Non-Traditional Threats
}

\author{
Muhammad Suryadi, Fauzia Gustarina Cempaka Timur \\ Asymmetric Warfare Study Program \\ Universitas Pertahanan \\ Kawasan IPSC, Sentul, Bogor, J awa Barat 16810, Indonesia \\ muhammad.suryadi@ hotmail.com \\ Submitted: August 15, 2018; accepted: September 26, 2018
}

\begin{abstract}
Abstrak
Tulisan ini berargumen bahwa pengaturan-pengaturan bilateral tidak lagi mampu mengatasi konvergensi ancaman non-tradisional, terutama karena longgarnya perbatasan di wilayah Asia Tenggara. Dengan demikian, kerja sama dalam menjaga perbatasan maritim dinilai lebih efektif dalam upaya perlawanan terhadap teroris. Artikel ini bertujuan mengamati ancaman non-tradisional yang berasal dari perbatasan maritim, khususnya di wilayah tiga negara ASEAN-Indonesia, Malaysia, dan Filipina-yang telah menandatangani Kerangka Kerja Pertahanan dan Keamanan pada tahun-tahun sebelumnya. Dari analisis Trilateral M eeting, dapat dilihat komitmen ketiga negara dalam menanggulangi FTF yang sudah menjadi tantangan ketidakamanan di Kawasan ASEAN. Selanjutnya, tulisan ini mempertimbangkan efektifitas Perjanjian Trilateral dalam memerangi ancaman non-tradisional termasuk terorisme.
\end{abstract}

Kata kunci: pejuang teroris asing, konter-terorisme, kerja sama keamanan, ancaman non-tradisional.

\begin{abstract}
This paper argues that bilateral arrangements among ASEAN countries are no longer enough to address the convergence of non-traditional threats, primarily due to porous borders in Southeast Asia region. Hence, fighting terrorism by securing maritime border through ASEAN border cooperation is seen as a useful measure to respond the issue. This paper aims to observe non-traditional threat posed from the maritime boundary, specifically from Indonesia, Malaysia, and the Philippines border which each of the government has agreed on Defense and Security Agreement Framew ork in the past few years. The FTF returnees and the existential threat of terrorism in each ASEAN countries have eventually carried a new agenda for ASEAN countries in securing the border. This paper then analyses the result of the Trilateral Meeting that depicts the commitment of these countries in tackling FTF as the growing security challenges in the region. This paper also considers the effectiveness of the Trilateral Agreement in combating non-traditional threats including terrorism.
\end{abstract} Keywords: foreign terrorist fighter, counter-terrorism, cooperative security, non-traditional threats.

\section{INTRODUCTION}

In May 2015, Singapore Prime Minister Lee Hsien Loong highlighted that Southeast A sia had emerged as a 'key recruitment centre' for ISIS (Samuel, 2016). Additionally, as written by Parameswaran (2015, para 3), Prime $M$ inister Leealso highlighted that, "Thethreat is no longer over there; it is over here." Eventually, terrorism threat has been a serious issue for ASEAN member states within its national security history. What is significant, however, is the changing situation of the international sphere brings on the possibilities of terrorism to establish a regional base that would pose an extraordinary threat to the whole ASEAN member states.

Jensen (2014b, para. 1) had pointed out that Southeast A sia was the third most active region in the world con- 
cerning terrorist attacks, with nearly 1200 attacks occurring in the area. The vast majority of terrorist attacks occurred during 2013 in two states of ASEAN members, the Philippines and Thailand. The attacks in those countries were accumulated and around $95 \%$ of the attacks occurred by the year.

The terrorist in Thailand was primarily confined to the southern part of the country, where some of the groups have been waging a separatist war since the mid-2000s (Jensen, 2014). M eanwhile, the terrorist in the Philippines was dispersed broadly across the country and was driven by a number of groups with various goals. For instance, the Moro Islamic Liberation Front (MILF) and the Bangsamoro Islamic Freedom M ovement (BIFM) are separatist groups based their movement on ethnicity and religion, while others contemporary terrorist groups, such as A bu Sayyaf G roup and M aute G roup are moreprominent terrorist organizations driven by ISIS's ideology with a mission to create M indanao as ISIS province in Southeast Asia.

In Indonesia, the terrorist attacks are mostly conducted by lone wolf terrorist. Lone wolf terrorism begins with a combination of personal and political grievances which form the basis of an affinity with other online sympathisers (H amm \& Spaaj, 2015). The threat of lone wolf terrorism occurred from the loose of controlling individual security that vulnerably exposed by radicalisation. All those lone wolves' attacks use ordinary items, like cars and knives, which make it hard to prevent. It is followed by the identification of an enabler, as well as by the announcement of terrorist intent. This situation explains theterrorist attack could also happen without any command and control from the main base. Channel News Asia (2017) published an infographic contained several incidents of terrorist attack in Indonesia affiliated with ISIS, such as twin suicidebombingin East Jakarta; bomb attack and shooting in Bandung, West Java; suicide bombing in Solo, Central Java; stabbing attack in Tangerang, Banten; as well as shooting and bomb attacks in Jakarta that happened in 2016 until 2017.

C onceptually, ASEAN seems to be well suited to combat the new non-traditional threats that affect the peoples in the region. Earlier than another regional organisation, in the late 1980s, ASEAN had adopted numerous com- prehensive security decision, both for traditional and nontraditional threats. M oreover, it has acknowledged that the necessity to increase transnational collaboration and cooperation to overcome challenges is at its peak through a regional meeting. In M ay 2017, the battle of M arawi in the Philippines has alarmed the member states to address terrorism with the unity of ASEAN. O therwise, the emerging of terrorism as a non-traditional threat capable of building a base in Southeast A sia will soon become a reality.

Katsumata (2009:2) on his book ASE AN 's C ooperative Security Enterprise was analysing the significance of cooperative security through ASEAN and three non-ASEAN countries, namely, C hina, the U nited States, and Australia by using a realist perspective. Hence, Katsumata's explanation stated that ASEAN approach emphasises dialogue and consultation with mutual understanding and trust are said to benaive and did not offer any mechanism to prevent or resolve the conflict. This paper is different from Katsumata's since it only implements the concept of cooperative security among ASEAN member states, particularly cooperation among Indonesia, Malaysia, and the Philippines.

N ayar (2013) in Cooperative Security for South Asia found the concept of cooperative security in the South A sian context is rarely discussed. Given the complexity of the hard security issues that divide various countries, discussion on these concerns at a regional level particularly in South A sian A ssociation for Regional C ooperation, has been regarded as a contradiction to the regional cooperation. Therefore, the South A sian Association for Regional Cooperation charter is reluctant to any further discussion on sensitive bilateral concern. Even outside of this forum, there are particularly a few discussions at bilateral or multilateral levels on regional security concern. However, Nayar's research had proven that South A sia did not have any regional security cooperation unlike Southeast Asia, where numerous of regional security cooperation has been established. N ayar's research also put a broader context of non-traditional threats such as terrorism, natural disaster, and environmental change, as well as economic development, instead of focusing on a single issue that become a core of concern in South A sia countries, while differently, this research paper put more specific explanation to con- 
temporary non-traditional threats. From the Nayar's research, it is concluded that the absence of such regional dialogue on security issues has given a significant impact on an atmosphere of mutual suspicion and distrust in the region.

The novelty of this paper is mainly the use of cooperative security as a single concept to generate an operational framework. This paper provides a condition where the concept of cooperative security able to show its significance exclusively among ASEAN member states. By using the descriptive-analytical method, this paper will analyse further by explaining terrorism cases in Southeast A sia as a classical issue for most of the countries that need to be seen through the unity. By agreeing to focus on terrorism as a common threat in the region, this paper exposes the necessity of common perspective from ASEAN member states to be addressed in regional level, instead of only in sub-regional level.

This paper aims to argue that terrorism as a non-traditional threat has not been addressed optimally in regional level by ASEAN through collaborative cooperation. The terrorist threat that keeps frequently coming as a national concern of each ASEAN 's is perceived as a sensitive issue which mostly dealt with sovereignty concern. Furthermore, this paper also aimed to provide an operational framework that eventually analyses the considerable problem of nontraditional threat that is coming from the mobility of people, as the terrorist method of recruitment and radicalization involving the role of people mobility that has not been given a concern. The research of this paper is also conducted to show that the absence of a common definition and agreement has hampered the solution to offer an operational framework to combat terrorism in more effective way.

This paper is urging ASEAN to rereading terrorism as a non-traditional threat that need to be addressed with unity. The existence of terrorist in Southeast A sia during the 50 years of ASEAN has not given any significant effect on regional security. C urrently, the terrorist group in Indonesia and the Philippines sea border has shown the vast impact on those countries. It indicates any effort and action claimed to combat the threat have not given significant changes. In addition, ISIS's influence to a certain terrorist group, FTF and lone wolf terrorist made a new concern in combating terrorism needs to be increased. This paper offers solutions for ASEAN member states to integrate regional security as part of national resiliencethrough the operational framework in combating terrorism as a common threat by using conceptual framework provided.

\section{CONCEPTUAL FRAMEWORK}

The advanced method of Cooperative Security embraces two concentric and mutually reinforcing 'elements of security': Individual Security (inward) and Territory Stability (outward). Of these two elements, Cooperative Security model is a common commitment to protect individual security and to promoting stability within a territory. This paper analyses that ASEAN can claim to effectively operate in two elements of Cooperative Security model through its system, values, and its member unity as the basis of regional security and producing operational framework as a guide to combat terrorism.

A $n$ idea that becomes a central concern within ASEAN member states is state sovereignty, where other state members are unable to involve in any situation unless it is declared. H owever, the concept of state sovereignty cannot be a screen to cover mass violations, or another threat to human security which can take place with impunity such as terrorism that recently occurred. Therefore, the Westphalia concept of the absolute right of states sovereignty fit within their territories is no longer accepted concerning the promotion of regional security.

Moreover, the component of Cooperative Security is the active promotion of stability outside the boundaries of the states that agree to establish the Cooperative Security system (C ohen \& M ihalka, 2001). Instability in areas where the nearby location of the region of the Cooperative Security system, or further afield, that might threaten the security of its members will become a matter of serious concern. Stability may be overturned by the danger of conflict between states, or even further by mass violations toward individual security in neighbouring countries.

\section{METHODS}

The methodological approach utilised in this research paper aims to combine a theoretical and factual under- 
standing of ASEAN and the cooperation to combat terrorism as a non-traditional threat to the region. The methodology is constructed on a historical narrative. As a research practice, historical narration focuses on the description and interpretation of events (Moleong, 2014). The historical narrative implemented in this paper has a central subject on a specific aspect of terrorism history in Southeast A sia and the ASEAN, and covers a period from the few years. A historical approach is compulsory since the cooperative security factor has been significant at different periods of ASEAN in terms of seeing terrorism as a common threat. It is demonstrated that the characteristics of cooperative security in ASEAN have influenced most of their crucial moments and developments. Consequently, the use of such method provides the reader with a complete understanding of the role of each ASEAN 's member states within both cooperative security regimes. Theobjective of this study is to propose an alternative perspective towards ASEAN in responding to terrorism as a regional concern through an integrated system of collective security. This research is aimed not, however, to quantify the significance of the cooperative security factors in ASEAN simply because it is impossible to measure the relative importance of this specific dimension on the cooperative process.

\section{RESULT AND DISCUSSION}

\section{ASEAN AND ITS COUNTER-TERRORISM EFFORTS}

In 1967, ASEAN was established by five countries, namely, Indonesia, M alaysia, the Philippines, Singapore, and Thailand. The establishment of this regional body is aimed "to promote regional peace and stability through abiding respect for justice and the rule of law in the relationship among countries of the region and adherence to the principles of the U nited Nations C harter" (ASEAN, para. 3) with the key concept called ASEAN way. It constitutes the Southeast A sian pattern of diplomacy. It is a consultative process that is mainly motivated by the will to create a stable environment in the region (A ntolik, 1990).

At a very first place, the scepticism of ASEAN as a regional organisation which offer stability has been predicted in various times. At the beginning of its birth in 1967, few people thought it would last a decade since the two previ- ous attempts; namely, The Association of Southeast Asia and the MAPHILINDO (M alaysia, the Philippines, and Indonesia) concept had ended only a few years after their creation.

The failure of Southeast Asian former organisation was not only the main concern of the scepticism. The A sian financial crisis (1997-1998) and the global financial crisis (2007-2012) eventually has led ASEAN gave little attention of its impact on regional security. Buszynski (1999, para. 3) stated that the impact of an economy has further affected security relations between states in Southeast A sia. For instance, the Asian financial crisis has diverted the attention of ASEAN from C ambodia's political crisis and has undermined regional efforts to respond to the problem effectively.

Consequently, the ASEAN way has been dynamically changed from full respect to the principle of non-interference into the concept of 'enhanced interaction,' where it would allow qualified intervention upon the home affairs of the ASEAN 's member. RYU (2008) explained that the examination of the documents resulted from ASEAN Ministerial Meetings in 1998 to 2004 had revealed the change upon the strategic concept. N evertheless, the alteration of ASEAN 's concept in perceiving security discloses the principle contradiction to ASEAN's non-interference as the existing identity. The mechanism of ASEAN to reform the current contradiction between its original identity and the urgency to intercede the home affairs of ASEAN 's member will impact its future.

The following case such as, $1969 \mathrm{M}$ alaysia-Philippines problem over Sabah, 1975 U S-V ietnam, 1979 Vietnam invasion to $C$ ambodia, the end of the Cold War, and 1997 the A sian financial crisis, are historical problems that had created challenges for ASEAN. In addition, the border clashes between Thai-C ambodian do not inspire the confidence of ASEAN to promote regional peaceand stability through withstanding respect for justice and the rule of law in the relationship among countries of the region. Buszynski (1999, para. 5) pointed out that, "Simmering rivalries and mistrust continue to worsen relationships between Singapore and M alaysia, Thailand and Burma, and M alaysia and Thailand." H owever, today is a far cry from the 1960s and 1970s, and there are grounds for opti- 
Table 1. ASEAN R esponse towards Terrorism

\begin{tabular}{|c|c|c|}
\hline Place and Date & Forum & Outcome \\
\hline $\begin{array}{l}\text { Bandar Seri Begawan, } \\
\text { November } 2001\end{array}$ & 7th ASEAN Summit of M eeting & Declaration of Combating Terrorism \\
\hline $\begin{array}{l}\text { Bandar Seri Begawan, August } \\
2002\end{array}$ & Meeting with Dialogue Partner & $\begin{array}{l}\text { Declaration of ASEAN-US Cooperation to Combat } \\
\text { Terrorism }\end{array}$ \\
\hline Hanoi, J une 2003 & AMMTC Special Meeting of Terrorism & Plan of Action Combating Terrorism \\
\hline Chiang Mai, August 2004 & $\begin{array}{l}\text { ASEAN Intelligence Chief Meeting and } \\
\text { ASEANAPOL }\end{array}$ & Intelligence Information Sharing \\
\hline J akarta, J uly 2004 & 37th $A M M$ and PMC & $\begin{array}{l}\text { Declaration (ASEAN-Russia, ASEAN-Australia) } \\
\text { Cooperation in Combating International Terrorism }\end{array}$ \\
\hline Siam Reap, J une 2005 & $\begin{array}{l}\text { 5th Senior Officials Meeting on } \\
\text { Transnational Crime }\end{array}$ & $\begin{array}{l}\text { Reaching Consensus to prioritize the areas of } \\
\text { transnational crime in order; terrorism; illicit drug } \\
\text { trafficking; trafficking in persons; and money } \\
\text { laundering }\end{array}$ \\
\hline Phuket, J uly 2009 & 42nd ASEAN Foreign Ministers of Meeting & J oint Communique of Coping with Global Challenges \\
\hline Clark, October 2017 & $\begin{array}{l}\text { J oint Statement of Special ADM M on CVE, } \\
\text { Radicalization and Terrorism }\end{array}$ & $\begin{array}{l}\text { Strengthen cooperation at bilateral, regional and } \\
\text { international levels in combating terrorism }\end{array}$ \\
\hline
\end{tabular}

(Source: adapted from asean.org, 2018)

mism that these intra-ASEAN conflicts would not doom the organisation. M oreover, in the meantime, ASEAN gives a slight of hopes towards the future regionalism among the world, after the crisis happens in theE uropean U nion that ASEAN needs to takeits problem into account within its unique way.

As the financial crisis occurred in 1997 and criticism upon the performance of ASEAN in countering regional affairs of economic and political issues, ASEAN hasformed numerous policy to covers and tighten the loopholes. A charya (2013:1) explained that "ASEAN has eventually realised that the created situation has urged its vision to be upgraded in the meantime, to also cover economic, political-security, and socio-cultural under communities." Thus it finally determined to adopt the charter as legal form base to strengthen the compliance from its members to achieve greater institutionalisation and consolidation. Besides, ASEAN has performed several efforts by building the most recent mechanisms and tools in managing con- flict and collecting action upon the states member. M oreover, whereas ASEAN within 20 years of the presence focused on a certain range of matters, ASEAN's role now even has broadened rapidly (A charya, 2013). It functions now cover a variety of new transnational or non-traditional security issues, one of them is counter-terrorism. Below is the data of ASEAN response towards terrorism as a nontraditional threat:

As shown in Table 1, ASEAN numerously has given its response in combating terrorism. $0 \mathrm{n}$ the one hand, the declaration and plan of action made have adopted actions and conducted cooperation to address the issue. $\mathrm{O} n$ the other hand, from all results as stated in documents of ASEAN there was no single common definition of terrorism to emphasise the direction of where the all the cooperation aims to. Therefore, the situation in Southeast A sia is unable to be cleared from the threat of terrorism, although many responses have been made.

$N$ evertheless, instead of establishing a strong base of 
common perspective in combating terrorism, ASEAN has expanded its institutional model into a wider area that beyond Asia Pacific and East Asia region, such as the ASEAN Regional Forum (ARF), the East Asian Summit (EAS), as well as ASEAN Plus Three (APT). As ASEAN's Secretary-G eneral, Pitsuwan (2017, para. 2) has recently observed, "ASEAN has emerged as the fulcrum of geopolitical stability in A sia." Within five decades ASEAN has increased its membership to be growth not only quantitatively, but also qual itatively by creating more communities in responding the issue within its area. ASEAN realised that as regional organizations it needs to strengthen the partnerships along with all major countries as the dialogue partners as well as with external parties. The following are the examples of ASEAN's efforts to strengthen its relations and cooperation in responding issues that requires further cooperative dialogue and actions; namely, the ASEAN Plus Three, the AS-JSCC, the ASEAN Defense Ministers' M eeting (ADMM) Plus, the ASEAN Political and Security Community (APSC), and the ASEAN Regional Forum (ARF). All those efforts have given contribution upon the enhancement of mutual understanding and strategic trust to achieve peace, stability, and development cooperation with all countries regionally and internationally. Most essential, the centrality of ASEAN has been recognised in the changing of regional building (Sisoulith, 2017).

Kaur found that the Southeast $A$ sian region has seen a high level of predominantly intraregional migration since the 1980s (Larsen, 2010). International O rganization for Migration (IOM) has pointed out that these high levels of people movement have been driven by various socioeconomic and political push and pull factors operating throughout the region (Larsen, 2010). This situation occurred due to the heterogeneous region has a very strategic position, particularlygiven theimportance of searoutes, coastal countries, and spacious land boundaries between insular and peninsular Southeast A sia that make it vulnerable and easily accessed due to porous borders. Therefore, it has been easier for illegal migrant, illegal trafficker, as well as terrorists to travel across from one to another place. Particularly for terrorism that remains a sensitive topic, since it hinges on sovereignty issues. The loosening of bor- der control and the ignorance to coordinate action among ASEAN members has made terrorist free to plan, exercise, and conduct their assaults without control ( $C$ abalza, para. 3). Likewise, the Philippines prohibits foreign forces from directly engaging in actual combat on their land.

In 2017, A SEAN has turned 50 years and been through several crises including territorial crisis between its members. For instance, dispute between Indonesia and M alaysia on the sovereignty over Sipadan and Ligitan Island, dispute border of Preah V ihear temple between Thailand and $\mathrm{C}$ ambodia, dispute of sovereignty over Pedra Branca between Singapore and Malaysia, dispute of the Philippines retains a claim on the eastern part of $M$ alaysia, and the ongoing dispute of South China Sea among several sovereign states within the region namely Brunei, the People's Republic of C hina (PRC), the Republic of C hina (ROC ), M al aysia, Indonesia, the Philippines, and $V$ ietnam.

The current ASEAN's status with its grown ten member states had made ASEAN be situated itself at the heart of regional architecture and successfully showing considerable impact towards the peace and prosperity within Southeast Asia (0 ba, 2010, para.1). In addition, 0 ba (2010, para. 1) stated that "the Association has been seeking Southeast A sian integration, announcing the establishment of the ASEAN Community, the first regional community in Asia, in December 2015." On the one hand, these achievements which had been made by ASEAN are all noteworthy. On the other hand, the future challenges towards ASEAN have shifted onto non-traditional threat, particularly foreign terrorist fighter.

The changing situation of the world since cold war has raised countries' awareness to put more concern in strengthening their security. Since September 11, 2001, the concept of non-traditional security issues has become increasingly common in almost all parts of world included in Southeast Asia, both domestically and regionally: in the policy and the research agendas of governments, in nongovernmental organisations, in academic circles, as well as in the general public and the media (Wang, 2004). Traditionally, security has been defined in geopolitical terms and confined to relationships among nation-states, dealing with issues such as deterrence, the balance of power, that lead to military strategy, capacity, and capability. H ow- 
ever, the non-traditional understanding of security has increasingly focused on whether a given issue represents an existential threat, typically to a state or non-state actor. N on-traditional security issues are started by the increasing of people mobility which has caused further concern in transnational crime, foreign terrorist fighters, and refugee as a core national security issues.

The process of ASEAN integration among its member had faced various challenges, particularly when it comes to security issue related to the territory. The sovereignty and the ASEAN Way values of non-interference as a vital principle are eventually making regional security handicap. This is one of the influential factors why the terrorist conundrum has lasted so long in ASEAN countries. C abalza (2017, para. 7) stated that, "despite tactical and operational support from ASEAN neighbours and major powers to combat terrorists, military cooperation at the ASEAN level remains limited due to the member-states' sensitivities and national sovereignty concerns, such as different approaches to national defence and cooperation, as well as different levels of development, equipment, and operational procedures that reflect the region's inherent complexities."

\section{DEFINING TERRORISM HELPS FINDING EFFECTIVE COUNTER- TERRORISM APPROACH}

The definition of terrorism has not gained any universal acceptance due to the different perspective of every state national interest. The Philippines in Republic Act no. 9372 stated any person who commits an act punishable under any of the following provisions of the Revised Penal C ode: Piracy in general and mutiny in the high seas or in the Philippines water; rebellion or insurrection; coup d'état; murder; kidnapping and serious legal detention; and crimes entailing ruination through planning, making a situation to be escalated and cause massive fear as well as creating panic within the population, in order to expose threat towards the government (IAG, 2017).

Lao PDR in Art. 8 Law on Anti-M oney Laundering and Counter Financing of Terrorism defined Terrorist as a natural person, a group of people, an organisation or a terrorist organisation that commit an act as defined in Article 7 of this law. Meanwhile, Article 84 of the $\mathrm{Crimi-}$ nal C ode of the Socialist Republic of V ietnam as quoted by Vinh (2017) defined terrorism as a form of violation that purposely aimed to destroy both life and physical health of a person and the government. Furthermore, it is also perceived as one of the actions which destabilise foreign relations of Vietnam towards other countries where it has relations with the act of terrorism.

A part from the various definition made by those countries, the ASEAN states have in recent years formulated a common rhetorical position and indicated their willingness to work together to combat terrorism. Joint declaration has included the Declaration on Joint Action to Counter Terrorism issued in November 2001 and a second D eclaration on Terrorism signed at the ASEAN summit in Phnom Penh in early November 2002. December 1997, the ASEAN Ministerial M eeting on Trans-national Crime (AM M TC) was set up and brings together the respective home ministers and constitutes the core of ASEAN's counter-terrorism collaboration. H owever, the more recent AM M TC meetings have been disappointing, failing to contribute to the fight against terrorism. Their joint communiques readopted well-known rhetorical measures. It is thus not surprising that many of responses made by ASEAN towards terrorism are mostly made by a subASEAN level, such as through bilateral or trilateral agree ments.

Combating terrorism requires a thorough analyses and assessment from counter-terrorism agencies, inter-agency coordination, intelligence sharing, improved institutions, and enhanced military capabilities that demand all ASEAN countries to cooperate and coordinate further in a firm way, such as on agreement, treaties, or more specifically sub-region cooperation. Fronting various problems in the contiguous-border area will require strong commitment by concerned states, such as foreign terrorist fighters issue need to be handled by Indonesia, M alaysia, and the Philippines in Sulu and C elebes Sea.

Through security perspective, the Sulu and C elebes Sea or also known as tri-border area that link Indonesia, Malaysia and the Philippines lies as challenges as well as the potential opportunities for greater multilateral cooperation among three countries. $\mathrm{n}$ the one hand, the C elebes Sea opens southwest through the Makassar Strait, which 
Table 2. A bu Sayyaf G roup Terrorism Activity within Sea B order

\begin{tabular}{|c|c|c|}
\hline No. & Year & Case \\
\hline 1. & 2000 & $\begin{array}{l}\text { Kidnapped } 20 \text { hostages from Malaysian resort: Malaysian govemment employees, a police officer, a Filipino } \\
\text { hotel worker and tourists from France, Germany, South Africa, Lebanon and Finland. }\end{array}$ \\
\hline 2. & 2011 & $\begin{array}{l}\text { Australian national Warren Richard Rodwell was abducted from his residence in Ipil, Mindanao and held for } \\
\text { ransom until } 2013\end{array}$ \\
\hline 3. & 2012 & A Swiss and a Dutch were kidnapped near the Tawi-Tawi Islands \\
\hline 4. & 2014 & $\begin{array}{l}\text { The group killed at least } 21 \text { Muslims celebrating the end of Ramadan on the Island of J olo. } \\
\text { Kidnapped two Germans in Palawan Province for six months }\end{array}$ \\
\hline 5. & 2015 & $\begin{array}{l}\text { A coast guard boat and crew were kidnapped and the captain was found beheaded. } \\
\text { Abu Sayyaf beheaded Bernard Then, a Malaysian businessman kidnapped from a seafood restaurant inside } \\
\text { Malaysia. }\end{array}$ \\
\hline 6. & 2016 & $\begin{array}{l}\text { Indonesian sailors were abducted from the Brahma } 12 \text { tugboat and the Anand } 12 \text { barge in the waters off the } \\
\text { southem Philippines in March. }\end{array}$ \\
\hline
\end{tabular}

(Source: Hume \& Kathy, 2016)

is increasingly used by large crude oil tankers that could not pass the shallower route in Strait of Malacca. Even though the number of global trades passing through the tri-border area is considerably less than the number passing through the Strait of $M$ alacca, yet it is nonetheless substantial. In 2015, for instance, more than 100.000 ships and 18 million passengers passed through the Celebes and Sulu Sea, with a cargo value of around $\$ 40$ billion. Besides, trade among the tri-border states is also growing. Worldview Startfor (2016, para. 5) found out that, "the Philippines, for instance, depends on Indonesia for 70 percent of its coal imports, valued at approximately $\$ 800$ million."

On the other hand, the massive flow of trade through these waters has allowed such practices to persist, providing funds for militant and organized crime groups, namely A bu Sayyaf G roup. Wallis (2017, para. 3) pointed out that, "the Sulu and Celebes area is the world's fastest growing piracy hotspot under A bu Sayyaf Group with violent attacks on commercial vessels and their crews, and an increasingly successful kidnap and ransom business model that mostly coming from ASEAN C ountries citizens itself." Table 2 are the recent actions of terrorism conducted by A bu Sayyaf G roup.
The growing number of cases occurs in Sulu and C elebes Sea has given the terrorist a clear picture that the tri-border has not been strongly protected by Indonesia, Malaysia, and the Philippines in any form of security cooperation and has offered an opportunity for them to spread and connect each other transnationally. However, this problem has not been seen as a crucial concern that needs to be addressed immediately as it became a classic case among ASEAN countries.

In fact, the growing influence and aspirations of ISIS been able to exert in Southeast Asia, is both significant and great concern. The January 2016 attacks in Jakarta; the growing number of citizens in this region who find their way to Syria and Iraq to participate in the conflict; the rising number of FTF returning to the region to 'bring back the war to the home front;' the increasing number of terror groups pledging bai'ah to ISIS and finally the establishment and growing prominence of Katibah Nusantara or the ' $M$ alay Archipelago U nit for the Islamic State in Iraq and Syria in Southeast A sia region;' a component of ISIS staffed solely by personnel from Indonesia and Malaysia, are some of the indicators of ISIS's influence in Southeast Asia (Samuel, 2016). The main current crisis is the $M$ aute $G$ roup who pledged al legiance to IS $C$ aliph $A$ bu 
Bakr al-Baghdadi in A pril 2015. Since their current location presence is at Lanao del Sur Province, the group then labelled themselves 'IS R anao,' where it was implied upon the archaic title of the place (Franco, 2017).

Regardless the fear and panic exposed by numerous groups of terrorist within Southeast A sia region, such as in Indonesia during 2000's when the bombardment attack occurred in Bali and Jakarta, has shown the status of the regional security was eventually at risk (A charya, 2013). N owadays, the changing of terrorism nature to be modern terrorism is perceived as transnational threat by most countries, since the capability of radical groups shown in building plan as well as and executing it into targeted countries. It also exhibit surprising cases, acting across states, funds laundering and other types of support sent by its worldwide connection. H owever, looking back to the efforts by ASEAN member states, after a period of hesitancy, it can be said there are advance improvements where numerous forms of cooperation with two or more countries intraASEAN and extra-ASEAN, such as intelligence sharing and counter-terrorism cooperation which were taken in responding the regional issues as common threat that are on top of ASEAN agenda and priority (A charya, 2013).

In responding the influence of ISIS towards Southeast A sia terrorism, it is necessary to provide a proper perspective. ASEAN member states should bear in mind that there is a presence of 'ISIS Southeast A sia' threat, whereISIS at themain part officially announced its interest in any Southeast A sian country. For the most part, the existence of ISIS in Southeast A sia is strongly showed by the radical groups as well as any individuals who have performed bai'ah of allegianceupon ISIS. In other words, the ISIS case is somehow overlapped with the local jihadis' aim and vision. Kruglanski and Fishman (2006) found that this situation to be explained through integrated model approach where according to this model, individuals are searching for meaning and sense to their life and commitment into very tied groups like terrorist organisations fills this need of being part of something, making worth their living.

Therefore, it suggests further action and consideration as a consequent of the appeal of ISIS in Southeast Asia that create different approach depending on the country. For instance, in M alaysia and Singapore, it has mostly been the eschatological ideology and theology of ISIS that become the main reason of allegiance. While in Indonesia, the effect of ISIS covers on religious appeal. Moreover, other reasons have also been cited to explain this situation, for instance kinship networks and loyalties, group/ personal rival ries, personal and pragmatic interests towards ISIS. Thus, the terrorism pattern in Indonesia is considerably more complex and variegated compared to other Southeast A sian countries.

H owever, in the southern Philippines, groups that have long engaged in violence for political and criminal reasons are now claiming allegiance to ISIS. Although Khatibah N usantara was originally built in Syria as the ISIS wing within Southeast A sian, not all FTF came to the place have ever joined it. For example, compare to uniting their groups along with the Indonesian-led Khatibah, numerous of Malaysians are indicated become the fighter together with Tunisian, French, and Algerian orderrian FTF (Liow). The similar cause factor for this was resulted from contention and dispute upon the leadership that was taught by Indonesian.

A $n$ ending fact came up according to the critical issue of foreign fighters returning to Southeast A sia. Given how A sians terrorist involved in Afghanistan's war facing the Soviet U nion in 1980 as well as 1988, the fighters who survived then came to their homes with high dignity as for being a group of experienced fighters in Southeast A sia (H ashim, 2015). In addition, the plan of hardened a group of terrorists returning from the similar situation such as al so from Syria, they carry al ong the ideology, operational knowledge, as well as precious experience at mount war to be practically implemented in each of their home countries. This condition is a potential threat that cannot be ignored or even taken lightly by ASEAN.

Practically, the obstacle faced in Southeast A sia region as a whole is the policing and governance of the sea border encompassing three areas, namely the Sulu Sea (Philippines), waters of Sabah (Malaysia), and the Celebes/ Sulawesi Sea (Indonesia). These porous and ungoverned regions will worsen by the fact that the mobility of terrorist groups across borders is not under controlled (Liow). At the current situation, Indonesia, M alaysia, and the Philippines, ASEAN states member initiated dialogue and 
exchange of intelligence as well as information in numerous forms. In June 2017, these three countries reaffirmed their governments' commitment to effectively address existing as well as emerging transnational challenges and threats resulting to agree on 15 points on Joint Statement Trilateral M eeting among Indonesia, Malaysia, and Philippines that has been published on Indonesian Foreign Ministry (Kemlu, 2017). This agreement theoretically has covered some of the transnational issues that mostly faced by the parties, they are: extremism, socio-economic, intelligence and information sharing, terrorist financing, terrorist networks in IT, illicit and arms smuggling, military and law capacity training, religious leaders involved in deradicalisation, as well as protection for victim, women and children from terrorist threat.

$\mathrm{H}$ owever, the manifestation of cooperation needs to be taken one or two steps further, to involve joint patrols and where necessary, joint operations. On the one hand, there is a huge expectation of the implementation of the trilateral agreement between Indonesia, M alaysia, and the Philippines could run up against rigid mindsets, obsolete paradigms, and the perennial reluctance to compromise sovereignty. On the other hand, none of ASEAN efforts has given significant impact in reducing the number of terrorist threats. Cooperation between agencies within the various Southeast $A$ sian governments specifically, between themilitary, police, and intelligence could al so be improved through operational framework established from thecommon perspectives of all ASEAN member states. Through this way the all ASEAN member states are believed could contribute by way of military training programs, intelligence data sharing, as well as the transfer of operational knowledge.

The successful effort of the cooperation, however, needs to be conducted through different strategy approach in overcoming the non-traditional threat. ASEAN member states should be realized that every issue has its own character that needs a compatible tool to be utilised. Given the same case that has been made through M alacca Straits Patrol initiated by Malaysia, Singapore, and Indonesia, where only during several years of its launching the cooperation has been successfully decreased the number of piracy and armed robbery in M alacca Straits. The key point is laid on the construction process approach that utilised to form the trilateral frameworks in facing the nature of non-traditional threat, which makes it different with other cooperation that mostly conducted by track-one diplomacy in ASEAN. It was identified that the journey of M alacca Straits Patrol such as Eyes-in-the-Sky was started in ShangriLa Dialogue 2005 by involving not only government representative but also intergovernmental organisations, selected ocean law and maritime security experts and academician on the legality, justification and political implications of the initiative which considered as track-two diplomacy or non-traditional approach. This new way of diplomacy is preferred to address the issue of non-traditional threat in ASEAN. The idea of constructing a framework through track-one diplomacy or traditional approach between stateto-state relations in some points particularly in ASEAN has somehow collided with the issue of sovereignty. Thus the framework is occasionally dragged onto a pointless discussion with no consensus. H owever, the execution resulted from track-two diplomacy is necessary to be followed-up by authorities involved in track one diplomacy, in order to be officially agreed on behalf of thestate's policy. The explanation given above is only an example of sharing intelligence information as part of the framework in addressing non-traditional threat, the other security cooperative measures likewise in military and police cooperation could also be raised through the equal scheme used in establishing counter-terrorism efforts.

\section{CONCLUSION}

Terrorism existence in Southeast A sia is no longer considered as a recent threat that needs to be addressed as if it is new by the member states. In many terrorism cases occurred in Southeast Asia, there must be a lesson learned as an input material to cope better in combating terrorism in future. The reasons that hamper the process in ASEAN is the member-states' sensitivity and the concern of national sovereignty, such as different approaches to national defence and cooperation, different levels of development, equipment, and operational procedures that reflect the inherent complexities of the region.

It needs to be realised that the growth and the emergence of terrorist-affiliated transnationallyin Southeast Asia 
occurred due to the disunity system that made this region become a haven for the terrorist to be well connected. Furthermore, the wide of the geographical condition of Southeast Asian has made another challenge for states' member in securing the area. The inability of ASEAN member states to secure the border as unity has eventually created a natural security border gap for people mobility to cross because of particular reason; for instance, different priorities of national concern, financial responsibility to conduct a real-time patrol, as well as limited resource and capacity. This uncontrolled situation has led terrorism to growth more fertile and taking granted where it could also threaten the individual security as the target of radicalisation.

The emergence of ISIS in Southeast A sia and the traction it generates, illustrates how resilient and evolutionary the threat of terrorism has become. Because of this reason, regional governments must remain vigilant to ISISrelated developments, particularly pertaining the monitoring of both returnees and communications between militants in Syria and their counterparts as well as followers back home. They must equally be prepared to progress with the threat concerning counter-terrorism strategies, narratives, and cooperation. H owever, individual security also plays a vital rolein the emergence of terrorism. This is an implication of the absence of optimisation security border in the region where the loose of territory control has led people mobility across border uncontrolled and creates a haven for terrorist to be more developed. Thus, the neglection of controlling and monitoring rapid people mobility across border needs to be more pronounced in term of individual security protection.

The operational framework aimed to be utilised as a guide for combating regional terrorism. It further could be implemented as regional security cooperation, particularly for the regional organisation where most of the member states are in developing countries. Since it is necessary for these countries to realise the most fundamental concern begin from individual security that mostly abandoned. Moreover, it comes to a broader scope in which regional security demands stronger commitment from the countries to fully implement the cooperative security. This operational framework considered as a non-traditional way to cope with terrorism in which non-traditional threat re quires a non-traditional approach to handle the issue.

Consequently, this research paper suggests that ASEAN need to establish an operational framework based on a mutual and common perspective of terrorism. The operational framework is designed to promote mainstreaming and encourage activities from a long-term perspective. Its particular objectives are the following: to raise awareness; focusing on the definition of terrorism as a region threat that also need to be addressed through regional way; to encourage looking ahead; identifying a vision, priorities and necessary processes for creating Southeast A sia as a stable and peaceful region; to improve ASEAN member states security capacity in order to achieve greater and better collaboration in facing the future coming threats.

\section{REFERENCES}

Acharya, A. (2013). ASEAN 2030: Challenges of Building a Mature Political and Security Community. ADBI Working Paper 441. Tokyo: Asian Development Bank Institute. Retrieved from http:// www.adbi.org/working-paper/2013/10/28/ 5917.asean.2030.political.

Antolik, M. (1990). ASEAN and the Diplomacy of Accommodation. Armonk, N.Y.: M.E. Sharpe.

Association of Southeast Asian Nations. (2018). ASEAN Political Security. Retrieved from https://asean.org/.

Buszynski, L. (1999). The Impact of the Asian Financial Crisis on Southeast Asia. Retrieved January 12, 2018, from http:// www7.iuj.ac.jp/research/workingpapers/PIRS_2000_02.html.

Chabalza, C. (2017, August 9). The Diplomat. Retrieved from https://thediplomat.com/.

Channel News Asia. (2017). Terrorism Threat remains at Highest Level in Singapore in Recent Years: MHA report. Retrieved January 5, 2018, from https://www.channelnewsasia.com/.

Cohen, R. \& Mihalka, M. (2001). Cooperative Security: New Horizons for International Order. Retrieved from http:// www.marshallcenter.org/mcpublicweb/mcdocs/files/College/ F_Publications/mcPapers/mc-paper_3-en.pdf.

Franco, J. (2017). The Maute Group: New Vanguard of IS in Southeast Asia? Singapore: Rajaratnam School of International Studies.

Hamm, M. \& Spaak, R. (2015). Lone Wolf Terrorism in America: Using Knowledge of Radicalization Pathways to Forge Prevention Strategies. Retrieved from National Institute of Justice website https://www.ncjrs.gov/pdffiles1/nij/grants/248691.pdf.

Hashim, A. S. (2015). The Impact of the Islamic State in Asia: Policy Report. Singapore: S. Rajaratnam School of International Studies, Nanyang Technological University.

Hume, T. \& Qutiano, K. (2016). 10 Indonesian Hostages Released by Islamist Militant Group, President Says. Retrieved January 5, 2018, from http://www.cnn.com/. 
Jensen, M. \& Kammerer, W. (2014a). Infographic: Terrorism in Southeast Asia - Serious, Violent, And Unique [Graphics]. Retrieved from https://warontherocks.com/2014/07/ infographic-terrorism-in-southeast-asia-serious-violent-andunique/.

Jensen, M. (2014b) Infographic: Terrorism in Southeast Asia Serious, Violent, And Unique, Retrieved January 21, 2018, from https://warontherocks.com/2014/07/infographic-terrorism-insoutheast-asia-serious-violent-and-unique/.

Katsumata, H. (2009). ASEAN's Cooperative Security Enterprise: Norms and Interests in the ASEAN Regional Forum. New York: Palgrave Macmillan.

Kementerian Luar Negeri Indonesia. (2017). Joint Statement Trilateral Meeting on Security among the Philippines, Indonesia, and Malaysia, Kementerian Luar Negeri Republik Indonesia. Retrieved from https://www.kemlu.go.id/.

Kruglanski, A. W. \& Fishman, S. (2006). The Psychology of Terrorism: 'Syndrome' versus 'Tool' Perspectives. Terrorism and Political Violence, 18, pp. 193-215. http://dx.doi.org/10.1080/ 09546550600570119

Larsen, J. J. (2010). Migration and People Trafficking in Southeast Asia. Trends and Issues in Crime and Criminal Justice, No. 401, Australian Institute of Criminology.

Liow, J. C. (2017). ISIS in the Pacific: Assessing terrorism in Southeast Asia and the threat to the homeland, Brookings. Retrieved from https://www. brookings.edu/.

Moleong, L. J. (2014). Metodologi Penelitian Kualitatif. Bandung: PT Remaja Rosdakarya.

Nayak, N. (2013). Cooperative Security Framework for South Asia. South Asia Economic, 14, pp. 343-375. https://doi.org/ $10.1177 / 1391561413500190$

Oba, M. (2017, October 16). Challenges for ASEAN As It Turns 50, The Diplomat. Retrieved from https://thediplomat.com/.

Parameswaran, P. (2015, May 30). Singapore Warns of Islamic State Base in Southeast Asia, The Diplomat, Retrieved from http:// thediplomat.com/.

Pitsuwan, S. (2011, June 15) The ASEAN Heart of Asia, Jakarta Post, Retrieved from http://www.thejakartapost.com/.

Rafa, E. (2017). Islamic State Linked-Terrorist Attacks [Graphics]. Retrieved from https://www.channelnewsasia.com/news/ singapore/terrorism-threat-remains-at-hig hest-level-insingapore-in-recent-8902732.

Samuel, T. K. (2016). Radicalisation in Southeast Asia: A Selected Case Study of Daesh In Indonesia, Malaysia and the Philippines, Kuala Lumpur: The Southeast Asia Regional Centre for CounterTerrorism (SEARCCT). security.community/.

Sisoulith, T. (2017). ASEAN: 50 Years After and Into the Future. The ASEAN Journey: Reflections of ASEAN Leaders and Officials, 1 , pp. 111-115, from www.eria.org/asean50-vol.1.full-report.pdf.

Southeast Asia's Treacherous Waters. (2016) Retrieved January 5 2018, from https://worldview.stratfor.com/article/southeastasias-treacherous-waters.

Vinh, P. K. (2017) Vietnamese Law on Counter Terrorism, Retrieved 16 January from, http://www.iadllaw.org/

Wallis, K. (2017). Shippers Avoid New 'Pirate Hotspot' in Waters West of the Philippines, Retrieved January 5, 2018, from https:/ /www.reuters.com/.

Wang, Y. (2004). Defining Non-Traditional Security and Its Implications for China. China and World Economy, 12, pp. 966. Retrieved from http://citeseerx. ist.psu.edu/view doc/ download?doi=10.1.1.472.3779\& rep= rep1\&type=pdf. 